\title{
The Effect of Fasting on Health of Stomach Digestion System
}

\author{
${ }^{1}$ Masyitoh, ${ }^{2}$ Amelia Novita, ${ }^{3}$ Muhammad Farid, ${ }^{4}$ Andriyani, ${ }^{5}$ Suherman, ${ }^{6}$ Munaya Fauziah, \\ ${ }^{7}$ Najwa Khairina, ${ }^{8}$ Dina Rahma Fadlilah \\ ${ }^{1-8}$ Faculty of Public Health, Muhammadiyah University of Jakarta \\ K.H. Ahmad Dahlan Street, Cireundeu, Ciputat, South Jakarta, 15419 \\ E-mail: andriyani@umj.ac.id
}

\begin{abstract}
The human body has important digestive organs such as the stomach. One of the stomach diseases that is gastritis or ulcers has indeed begun to be experienced due to a lack of knowledge about the factors that cause gastritis and behavior to prevent the occurrence of gastritis. Gastritis known as ulcer disease is an inflammation or bleeding in the mucosa of the stomach caused by irritants, infections, and irregularities in the diet. The method used is a literature review article by reviewing 7 journals published from 2010-2020 about the effect of fasting on the health of the stomach digestive system conducted in April 2020. The results of changing dietary patterns during fasting cause various changes in the body, especially in the digestive tract. Fasting gives the digestive system time to rest, so it can reduce the risk or cure health problems indigestion. The conclusion is that there is a relationship between diet, knowledge, and stress to the incidence of gastritis. While in the behavior of coffee consumption and sex there is no association with the incidence of gastritis.
\end{abstract}

Keywords: Stomach Digestion, Gastritis, Fasting 


\section{INTRODUCTION}

To be able to improve the degree of public health, many things need to be considered. Indonesia from adolescence to old age, one of the contributing factors is considered to have an important role in maintaining health. The human body has important digestive organs such as the stomach. One of the stomach diseases, namely gastritis or ulcers has begun to be experienced due to a lack of knowledge about the factors that cause gastritis and behavior to prevent the occurrence of gastritis. Gastritis known as ulcer disease is an inflammation or bleeding in the gastric mucosa caused by irritating factors, infections, and irregularities in diet, such as late eating, eating too much, eating fast, eating too much spice, and spicy. (Huzaifah, 2017)

According to the World Health Organization (WHO), the incidence of gastritis in the world is about 1.8-2.1 million of the population annually, in the UK (22\%), China (31\%), Japan (14.5\%), Canada (35\%), and France (29.5\%). In Southeast Asia about 583,635 of the population each year. The percentage of gastritis incidence in Indonesia according to the World Health Organization (WHO) is $40.8 \%$. The incidence rate of gastritis in some areas in Indonesia is quite high with a prevalence of 274,396 cases (Budiana, 2006). (Dwi Wahyuni Rumpiati Rista Eko Muji Lestariningsih, 2017)

The incidence of gastritis in Indonesia is quite high, from research conducted by the Indonesian Ministry of Health in 2013 the incidence of gastritis in several cities in Indonesia is high reaching $91.6 \%$ in Medan City, then in several other cities such as Jakarta 50.0\%, Denpasar 46.0\%, Palembang 35.5\%, Bandung 32.5\%, Aceh 31.7\%, Surabaya 31.2\% and Pontianak 31.1\%. (Novitasary, sabilu and Ismail, 2017)

Based on data on gastritis disease in Indonesia the prevalence of the disease is still quite high, coupled with the majority of the Indonesian population being Muslim and the holy month of Ramadan therefore researchers want to examine the influence of fasting on the stomach digestive system.

According to research conducted by (Istiqomah and Fadlil, 2013), digestive diseases are all diseases that occur in the digestive tract. This disease is a large group of diseases of the esophageal, stomach, duodenum first, second and third parts, jejunum, ileum, colon, sigmoid colon, and rectum. The digestive system in humans is one of the vital organs for the body, so the health of the digestive system is very important to maintain. Considering the function of the digestive system as a place or tool to digest every food and drink that enters the human body. (Soepomo, 2013)

Based on the background above it is seen that in Indonesia there is still quite a lot prevalence of gastritis disease, researchers are interested in researching the influence of fasting on the health of the digestive system of the stomach because when fasting the human digestive system works less than usual. 


\section{METHODS}

This article is a literature review article that examines 7 journals published from 2010-2020 about the effect of fasting on the health of the digestive system of the stomach conducted in April 2020.

\section{RESULTS AND DISCUSSIONS}

Research conducted by (Wahyuni, Rumpiati, and Lestariningsih, 2017) showed that out of 43 respondents who had a good diet there were 31 respondents (32.6\%) did not occur gastritis and 12 respondents $(12.7 \%)$ occurred gastritis. While of the 52 respondents who have a poor diet there are 2 respondents $(2.1 \%)$ with no gastritis and 50 respondents $(52.6 \%)$ occurred gastritis. Spearman Rank test results obtained a value of $\mathrm{p}$-value $=0.000$ means $<0.05$, then there is a meaningful relationship between diet and the incidence of gastritis. The correlation coefficient also obtained a value -0.713 . or negative correlation.

According to research conducted by (Huzaifah, 2017) shows that knowledge with good categories and positive category gastritis prevention behaviors as many as 124 respondents or (44.8\%) and knowledge with good categories and negative behaviors as many as 22 respondents or as much as (7.9\%). The knowledge picture is sufficient with positive preventive behavior as many as 56 respondents or (20.2\%), and negative behavior as many as 50 respondents or (18.1\%). The knowledge picture is lacking with positive behavior as many as 3 respondents or (1.1\%), and negative behavior as many as 22 respondents or $(7.9 \%)$. Based on the Spearman rank correlation test with a value of $r=$ 0.465 and $\mathrm{p}$-value $=0.000$. The value of $\mathrm{P}<\alpha=0.05$, and $\mathrm{Ha}$ is accepted which means there is a relationship between knowledge of the causes of gastritis and gastritis prevention behavior.

The results of research conducted by (Tussakinah, Masrul, and Burhan 2018) showed that the majority of gastritis events occurred in respondents with a job as a housewife $34.4 \%$. The majority of gastritis events in housewives can be caused by stress experienced. The many demands of work and responsibilities as a housewife with a job that tends to watch can cause stress. Stress that occurs will affect the behavior of the housewife including loss of appetite, changes in sleep patterns, decreased productivity and this will also affect the psyche in the form of excessive anxiety, decreased endurance in making decisions. If this stress occurs continuously it will affect a person. (Tussakinah, Masrul and Burhan, 2018)

The results of the study conducted by (Novitasary, Sabilu, and Ismail, 2017), showed that of 9 respondents $(100 \%)$ who consumed coffee that was at high risk and experienced clinical gastritis as many as 4 respondents $(44.4 \%)$ and 5 respondents $(55.6 \%)$ who consumed coffee that was at high risk and did not experience clinical gastritis. Meanwhile, of the 233 respondents (100\%) who consumed coffee that was at low risk and experienced clinical gastritis as many as 145 respondents $(62.2 \%)$ and 
88 respondents $(37.8 \%)$ who consumed coffee that was low risk and did not experience clinical gastritis. Using the Fisher's Exact Test obtained a value of $\rho=0.311$, the value is greater than the $\alpha$ (0.05). This shows that coffee consumption is not a determinant of clinical gastritis in students at the Faculty of Public Health, Halu Oleo Kendari University.

The results of the study conducted by (Sunarmi, 2018) showed that out of 35 respondents 20 female respondents experienced gastritis as many as 9 respondents (45\%), and of 15 male respondents who experienced gastritis as many as 8 respondents (53.3\%) Based on the results of statistical tests chi-square in can p-value $=0.884>\alpha=0.05$ then the decision Ha failed to reject Ho rejected means there is no significant relationship between the sexes with the incidence of gastritis. (Sunarmi, 2018)

Dietary changes during fasting cause various changes in the body, especially in the digestive tract. Fasting gives the digestive system time to rest, so it can reduce the risk or cure health problems indigestion. During fasting, the stomach is also not filled with food for several hours. At this time, stomach acid production will decrease to prevent the erosion of the stomach wall by acid. Therefore fasting can affect the health of the stomach digestive system.

Understanding Shiyam (Fasting) Shiyam according to Language means refraining from something. Shiyam according to the term means refraining from eating, drinking, spousal sexual intercourse, and everything that cancels from dawn to sunset with the intention of Allah. The basis of the intention of fasting is because of Allah:

1. Allah's word says, "But they are not commanded except to worship Allah by purifying him in righteous religion." [QS. Al-Bayyinah (98): 5]

2. Hadith of the Prophet Muhammad (peace be upon him): "From Umar r.a. (narrated) that the Prophet (peace be upon him) said: Verily all acts of worship must be with intention, and everyone depends on his intentions..." [Compiled by Al-Bukhari, Kitab al-Iman].

3. Hadith of the Prophet Muhammad (peace be upon him): "From Hafshah Ummul Mu'minin r.a. (narrated that) the Prophet (peace be upon him) said: Whoever does not intend to fast at night before dawn, then it is not valid to fast." [Estimated by AlKhamsah, see Ash-Shan'aniy, II, 153]. (Muhammadiyah, 2013)

For Muslims, the essence of fasting is to restrain all members of the body and five senses from things that are forbidden and forbidden by religion and to distance themselves from reprehensible attitudes. At the time of fasting the digestive organs (digestive tract and enzymes and hormones) can rest for 14 hours, while when not fasting the digestive vital organs will work to digest food continuously for approximately 18 hours while fasting the organs in our body rest from the hard work of grinding food. When fasting the stomach is in an empty state, food will be more easily 
absorbed and cause bad germs cannot survive, thus we can avoid various diseases. Then fasting can affect the health of the stomach's digestive system.

\section{CONCLUSIONS AND SUGGESTIONS}

Based on the results of the above exposure can be concluded that there is a relationship between diet, knowledge, and stress to the incidence of gastritis. While in the behavior of coffee consumption and sex there is no association with the incidence of gastritis. The advice is one good way to avoid gastritis when fasting is to start from a healthy way of life and always pay attention to the consumption of food and drinks that we drink every day from open to sahur and no less important always pay attention to psychological conditions so as not to have too much mind (stress).

\section{REFERENCES}

Dwi Wahyuni Rumpiati Rista Eko Muji Lestariningsih, S. (2017) 'Dietary Relationship With Gastritis In Adolescents', Global Health Science,2(2), pp. 149-154. Available at: http://jurnal.csdforum.com/index.php/ghs.

Huzaifah, Z. (2017) 'Knowledge Relationship About The Causes of Gastritis With Gastritis Prevention Behavior', Healthy-Mu Journal,1(1), p. 28. DOI: 10.35747/hmj.v1i1.62.

Muhammadiyah, P. P. (2013) 'Guidance of Worship in Ramadan', Yogyakarta (Gramasurya).

Novitasary, A., sabilu, Y. and Ismail, C. (2017) 'Determinant Factor of Clinical Gastritis in Students at the Faculty of Public Health of Halu Oleo University in 2016', Scientific Journal of Unsyiah Public Health Students,2(6), p. 183949.

Soepomo, P. (2013) 'Expert Systems For Diagnosing Gastrointestinal Diseases Using the Dempster Shafer Method', 1(1), pp. 32-41. DOI: 10.12928/jstie.v1i1.2502.

Sunarmi (2018) 'Risky Factors With The Incidence of Gastritis Disease In Polyclinic Diseases In Muhammadiyah Palembang Hospital in 2018', Scientific Journal of Multi-Science Health, 8.

Tussakinah, W., Masrul, M. and Burhan, I. R. (2018) 'Relationship of Diet and Stress Levels to Gastritis Recurrence in The Work Area of Tarok Health Center of Payakumbuh City in 2017', Andalas Health Journal,7(2), p. 217. DOI: 10.25077/jka.v7i2.805. 
Volume I Tahun 2021

November 2021
E-ISSN: 2808-5361

http://e-journal.fkmumj.ac.id/
Proceeding The First Muhammadiyah InternasionalPublic Health and Medicine Conference 